\title{
An analytical study on impact of international financial reporting standards on financial statements and ratios of Indian companies
}

\author{
Dr. Nabha Kamble \\ Associate Professor \\ Jawahrlal Nehru Arts, Commerce \& Science College, Wadi.
}

\begin{abstract}
India is one of the emerging economies in the world. For economic development, foreign direct investment (FDI) is needed, to facilitate the investment climate. There is a need to integrate its financial reporting with rest of the economies of the globe so that investors from outside will appreciate the financial results and financial positions of the companies. This will provide uniformity and comparability of financial statements with the financial statements prepared in other countries. At present, Indian companies are preparing their financial statements as per Generally Accepted Accounting Principles in India (Indian GAAP). These Principles are based on IFRS issued by International Accounting Standard Board (IASB). However, these principles were modified substantially as per Indian laws and practices.
\end{abstract}

Key Words: - IFRS, IASB, Accounting etc.

\section{Introduction:}

The IFRSs issued by International Accounting Standard Board (IASB) are being followed in more than 114 countries of the world. However, the major economies like, USA, Japan and India are yet to follow these Standards. The objective of the following the IFRSs is to speak one accounting language all

\section{Co 1 over the world. The Idea of global harmonization of Accounting} Standards stems from lack of comparability of financial statements across the world. In particular, a company having presence in different countries has to prepare financial reports as per Generally

Accepted Accounting Principles of the country of operations and then it is required to reconcile all such reports for the purpose of consolidation as per Accounting Standards of the country to which the parent company belongs.

The need to communicate across the borders has increased with the increase in global trade and globalization of capital markets. Company in one country is borrowing in the capital market of another country. Therefore, financial statements produced in one country are used in other country more and more frequently; this has raised the issue of harmonization of accounting policies, presentation, disclosure, etc. Harmonization in the accounting context may be defined as the process aimed at enhancing the comparability of financial statement produced in different countries accounting regulation. Investors would like to direct their capital to the most efficient and productive companies globally, provided 
they are in a position to understand their accounting reports/financial reports. Further rationale behind the harmonization is that, it will enhance the comparability of financial statement. This makes them easier to use across the border.

\section{Role of accounting standards:}

In today's complex economic environment, the financial reporting has become critical from the point of view of allocation of economic resources. For proper allocation of economic resources, it is imperative that financial information contained in the financial reports of Corporate is reliable, comparable and transparent so that the present and potential Investors and Creditors and other users can make rational investment, credit and similar decisions. This is achievable only if the financial reports are prepared and presented using high-quality Accounting Standards. By laying down rules and criteria for accounting measurements, Accounting Standards seek to bring about uniformity in Accounting Practices while providing a reasonable degree of flexibility to take cognizance of differences in circumstances of different enterprises. Accounting Standards are formulated with a view to harmonize different accounting policies and practices. The objective of Accounting Standards is, therefore, to reduce the accounting alternatives in the preparation of financial

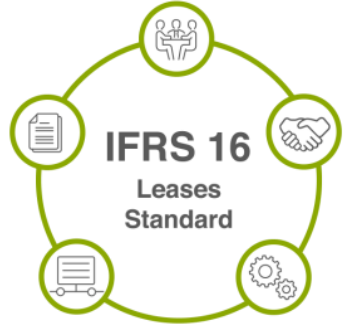
statements within the bounds of rationality, thereby ensuring comparability of financial statements of different enterprises with a view to provide meaningful information to various users of financial statements to enable them to make informed economic decisions.

The Accounting profession owes a responsibility for formulating Accounting Standards in order to satisfy the huge expectations of the society, in relation to reliable, credible and transparent financial reporting. It should also be noted that meaningful and transparent financial reporting serves an enterprise favorably in the long run since it establishes the creditability of an enterprise in the eyes of the Investors, Regulators and other users. Further, information about a particular Enterprise is greatly useful if it can be compared with similar information about other enterprises and with similar information about the same enterprise for some other period or some other point in time. Comparability between Enterprises and consistency in the application of methods over time increases the informational value of comparisons of relative economic opportunities or performance. The Investors and Creditors often use information for assessing their prospects for cash flows from investments in or loans to an enterprise.

\section{Role of ifrs in the global financial reporting:}

Keeping in view the different economic, social and legal environments, various countries such as USA, Japan and India, developed their own national Accounting Standards. In some cases, the Accounting Standards amongst different countries differ so significantly that conversion of financial statements prepared in accordance with the Accounting Standards of one country into the financial statements prepared in accordance with the Accounting Standards of another country could give substantially different results. For example, German industrial giant Daimler-Benz AG, which sought listing of its shares in the United States in 1993, ended up reporting a massive loss of $\$ 1$ billion under US GAAP, when in fact it had reported a profit of $\$ 370$ million under its own national (German) GAAP. In view of such significant differences, attempts have been made to harmonize the Accounting Standards between different countries. While different national traditions and experiences led to the development of alternative financial reporting models, the pressure for intensified 
development of the global environment has been evident as the needs of the ever-changing economies demand International harmonization. From an accounting perspective, the complexity of conducting International business operations across national borders, each with a different set of business regulations and often different accounting methods presents a daunting challenge for accountants and the professional bodies that establish accounting and auditing rules. This has resulted in the great attention being paid to harmonization of Accounting Standards at international level. Harmonization is a process of moving away from diversity towards harmony. Harmony is achieved where clusters of very similar practices are identified. Harmonization is achieved by a gradual process of mutual understanding and adaptation. The most effective body seeking to promote harmonization on

\section{IFRS:}

In the year 1959 the first step towards International Accounting Standards (IAS) was taken. The work of developing International Accounting Standard began (Choi, Frost, \& Meek, 1999). Since then, the work of accounting and non-accounting organizations concluded in the form of setting up of the International Accounting Standards Committee (IASC) in 1973. IASC is governed by 22 trustees, chaired by former US Federal Reserve Chairman Paul A Volcker. The IASC Foundation is funded by contributions from the major Accounting Firms, Private Financial Institutions and Companies throughout the world, Central and Development Banks, and other International and Professional Organizations. In 1997 the IASC changed its structure to bring about convergence between national accounting standards and practices and high-quality global accounting standards. It was the body which issued International Accounting Standards from 1973 to 2000. In 2001 IASC was replaced by International Accounting Standards Board (IASB), which assumed the responsibility for publicizing international accounting standards. IASB is an independent body and consists of members from nine different countries around the globe having variety of functional backgrounds.

International Financial Reporting Standards (IFRS) the new version of International Accounting Standards (IAS) are issued by IASB. It adopted all the existing IAS (numbered 1 to 41) issued by IASC (before 2001) and decided that it will make amendments in the present IAS and all future standards issued will be termed as IRFS. IASB is reviewing the IAS and has amended as well as replaced some of them with new IFRS. Several interpretations of Standards have also been issued. Broadly, IFRSs refers to the entire body of IASB and IASC pronouncement. The purpose of this IFRS is to ensure that the financial statements under IFRS an entity, as well as their interim financial reports concerning a portion of the exercise covered by such financial statements, contain high quality information and provides benefit to users. The Asian financial crises of 1997-1998 marked a motivation for supporting international accounting standards, where many countries either adopted international accounting standards in their entirety, or with minor changes.

\section{Convergence of IFRS:}

"Current Accounting and Reporting Practices fail to meet the information needs of the stakeholders in the 21st Century. One of the critical solutions of this problem is Convergence with Highly Active and Proven International Accounting Standards (IAS) and International Financial Reporting Standards (IFRS). The convergence of Indian Accounting Standard (AS) is a crucial decision taken by Institute of Chartered Accountants of India (ICAI). The Indian Companies have to adopt IFRS and IAS mandatorily. The Convergence of Accounting policy 
has gained momentum in the current scenario at global level. The paper in this context provided historical background of IAS \& IFRS, no. of standards, problem of stakeholders at global level and also provide current position of these standards, comparison the Indian AS with IAS \& IFRS, problems due to convergence and finally comment upon the convergence and its impact over Indian industries. Not only the paper deals with the positive aspects of convergence like massive workforce \& India can be developed as a global accounting hub but also other aspects of the problem like Changes which is to be accepted under various laws like Companies Act, SEBI Act, Income Tax Act, RBI Act, IRDA and other Act”.

\section{Implication of IFRS:}

The implications of IFRS implementation are not going to be limited to merely revamping the accounting policies and procedures. Changes in reporting due to enforcement of IFRS will change how profitability (income statement) and asset position (balance sheet) of a company is disclosed to the outside world. The relationships with stakeholders and contracting parties may have to be reviewed and revisited.

O Due to definite treatment of preference capital as debt rather than equity, there may be changes in debt/equity ratios.

O IFRS mandates that convertible debt is divided into liability and equity, and proceeds of issue of such debt have to be allocated accordingly. This would impact capital structure and debt equity ratios.

- The interest coverage ratio may change which may trigger breach of covenants in loan agreements.

\section{Literature Review:}

Abad, D., Cutillas-Gomariz, M. F., Sánchez-Ballesta, J. P. and Yagüe, J. (2018) conducted a study "with the purpose of IFRS (IFRS), adopted mandatorily by European listed firms in 2005, is to increase the transparency and the comparability of accounting information, which should have led to improvements in these firms' information environments. This study uses market microstructure proxies for information asymmetry to examine the effects of IFRS adoption on the level of information asymmetry in the Spanish stock market. Therefore, they consider a setting with substantial differences between local standards - Spanish Accounting Standards (SAS) - and IFRS and where the level of enforcement is low. Bycontrolling for conventional determinants of information asymmetry and firms' characteristics that influence their information environments, they find a reduction of information asymmetry after IFRS adoption. Our findings suggest that the mandatory switch from local accounting standards to IFRS conveys benefits to the market, even when the enforcement level is not strong".

Giner, B. and Pardo, F. (2018) explained that "the new IASB and FASB models for leases aim to improve the quality of financial reporting. To this end, both standard setters impose the recognition of assets and liabilities for operating leases. Meanwhile, preparers have been strongly lobbying against these changes, as in their view the new treatment will lead to negative economic consequences. They undertake a value-relevance study to examine whether as-if capitalised operating leases are priced by market users in a relatively unexplored setting. They consider Spanish listed firms, and employ hand-collected data on operating leases disclosed in the notes to the financial statements to constructively capitalize the assets and liabilities.

Athma \& Bhavani (2018) present analysis of financial implications of voluntary adoption of IFRS by 10 select companies in India. Their study uses secondary data, uses Gray comparability index, t-test and F-test. They study 5 ratios (EBIT, GP, NP, Debt Equity and 
EPS) for 5 consecutive years 2011-12 to 2015-16. They find that there is no significant difference in 5 selected financial ratios as per Indian GAAP and IFRS.

\section{Problem Statement:}

Any new concept always includes of favourable and unfavourable aspects like two sides of a coin. It is true with IFRS which is globally recognized as a new concept of Accounting Standards. The favourable aspects are the opportunities and advantages and unfavourable are the challenges and problems associated with its implementation. Economic growth capital market expansion, improvement in accuracy and reliability of accounting information, better corporate governance, facilitation of merger or amalgamation, saving costs and a helpful tool for the accounting professionals etc. are the opportunities areas whereas fair value principle, cost of training, burden of training employees, time value of money, requirement of change in company law, banking law, regulation etc. are the major challenges and problems in the transition of Indian Accounting Standards (AS) to IFRS.

\section{Research Objectives:}

The objective of the proposed research are:

1. To understand the adaptability of transition to IFRS in Indian Corporate sector.

2. To assess the level of awareness and acceptance of IFRS applied in Indian corporate sector.

3. To measure benefits of current adoption of IFRS in the selected Indian Companies.

4. To measure major limitations of current adoption of IFRS in the selected Indian companies.

\section{Research Design:}

The proposed study i.e. "An analytical study on impact of international financial reporting standards on financial statements and ratios of Indian companies" is descriptive in nature which describes the impact of voluntary adoption of IFRS on financial position of the selected Indian Companies using statistical tools.

\section{Limitations:}

1. A sample of experienced chartered accountants, Cost accountants, Tax consultant, Company Accountant and Academician would be taken only from India because of lack of resources and time and other barriers.

2. Questionnaire respondents cannot be considered totally free from bias.

3. During collecting data by questionnaires from experienced chartered accountants, Cost accountants, Tax consultant, Company Accountant and Academician it cannot be treated as totally free from errors. All possible attempt was made to record the information as accurately as possible

\section{Bibliography:}

1. Abad, D., Cutillas-Gomariz, M. F., Sánchez-Ballesta, J. P. and Yagüe, J. (2018), Does

IFRS Mandatory Adoption Affect Information Asymmetry in the Stock Market?

Australian Accounting Review, 28: 61-78.

2. Giner, B. and Pardo, F. (2018), The Value Relevance of Operating Lease Liabilities:

Economic Effects of IFRS 16. Australian Accounting Review, 28: 496-511.

3. Bassemir, M, Novotny-Farkas, Z. (2018). IFRS adoption, reporting incentives and financial reporting quality in private firms. J Bus Fin Acc. 45(1), 759- 796.

4. Athma, D. M., \& Bhavani, A. (2018), Mergers in Banking Sector in India: An Analysis of Pre-\& Post-Merger Performance of SBI \& HDFC Bank, IOSR Journal of 
Business and Management (IOSR-JBM), 07-16.

5. Charitou, A, Karamanou, I, Kopita, A. (2018). Are analyst stock recommendation revisions more informative in the post-IFRS period? J Bus Fin Acc. 45(1), 115- 139.

6. Wang, X. (2019), Compliance Over Time by Australian Firms with IFRS Disclosure Requirements. Australian Accounting Review. doi:10.1111/auar.12267

7. Nguyen, L. and Rahman, A. (2019), From totalitarianism to capitalism - the case of IFRS adoption in Vietnam. Account Finance. doi:10.1111/ acfi.12472

8. Lin, S., Riccardi, W. N., Wang, C., Hopkins, P. E. and Kabureck, G. (2019), Relative Effects of IFRS Adoption and IFRS Convergence on Financial Statement

Comparability. Contemp Account Res, 36(1), 588-628 